\title{
INTRODUCTION: UNDERSTANDING LEGAL EVOLUTION
}

\section{Klaus Heine*}

Questions concerning the evolution of law have always attracted the attention of scholars. For example, in 1897 Judge Oliver Wendell Holmes wrote his seminal article 'The Path of the Law', in which he clearly points to the fact that the evolution of law is neither arbitrary, nor can it be determined by a human mastermind. Rather, the evolution of law follows a path on which humans can influence the development of law, but cannot change its direction without running the risk that society and the economy end up in turmoil.

There are other scholars who have pointed to the fact that law is not a static monolith, but a dynamic part of society. To mention a few well-known names, in no particular order: Weber, ${ }^{2}$ Durkheim, ${ }^{3}$ Dicey, ${ }^{4}$ Pound, ${ }^{5}$ Llewellyn ${ }^{6}$, Maine, ${ }^{7}$ Savigny ${ }^{8}$ and Vinogradoff. ${ }^{9}$

However, only recently, legal scholars, economists, sociologists and scholars from other disciplines have begun to explore the evolution of law in a more systematic and theoretically coherent way. Quantitative empirical research has also recently been utilised to obtain a better understanding of legal evolution.

One prominent concept in the study of legal evolution is that of path dependency, which adopts Oliver Wendell Holmes' idea that law-making can be understood as an ongoing process of standardisation and adaptation of legal routines. Thus, the concept of path dependency has become a powerful tool for the study of institutions in general, including informal norms, customs and culture. ${ }^{10}$ However, there is a drawback for the scholar who wishes to explain the evolution of law. Although path dependency is a useful concept, it is certainly not the only one which can be employed in order to explain legal development. For example, the concept of regulatory competition ${ }^{11}$ transfers insights from product competition to the sphere of law, and claims that the evolution of law can be best understood as a process of rivalry between different legal standards. At the end of this process, the law that prevails will be the one which provides the best costbenefit ratio for society. From this perspective, there is no path dependency in shaping law, but a continuous process of inventing and adapting law to the needs of society. ${ }^{12}$ However, it is also possible to explain the evolution of law from a macro-sociological point of view. In this case the evolution of law does not depend on the aggregated will of individuals, but on the power and influence of larger entities in political processes. For example, the relative power of groups (owners of large property, the working class, or social, political and technocratic elites) may shape and preserve the law of society. Other

\footnotetext{
Erasmus School of Law, Erasmus University Rotterdam.

O.W. Holmes, 'The Path of the Law', 10 Harvard Law Review 10 (1897).

M. Weber, Law in Economy and Society (1954).

E. Durkheim, The Division of Labor in Society (1947).

A.V. Dicey, Lectures on the Relation between Law and Public Opinion in England during the Nineteenth Century (1905)

R. Pound, Interpretations of Legal History (1930).

K.N. Llewellyn, The Common Law Tradition: Deciding Appeals (1960).

H. Maine, Ancient Law (1917).

F. von Savigny, Of the Vocation of Our Age for Legislation and Jurisprudence (1831).

P. Vinogradoff, Outlines of Historical Jurisprudence, Vols. I and II (1920-22).

10 D.C North, Institutions, Institutional Change and Economic Performance (1990); L.A. Bebchuk \& M.J. Roe, 'A Theory of Path Dependence in Corporate Ownership and Governance', 52 Stanford Law Review 1 (1999).

11 A. Breton, Competitive Governments: An Economic Theory of Politics and Public Finance (1996).

12 For an introduction into regulatory competition and its possible connection to the concept of path dependency see K. Heine \& W. Kerber, 'European Corporate Laws, Regulatory Competition and Path Dependence', 13 European Journal of Law and Economics 1 (2002).
} 
approaches to the understanding of legal evolution, which have different methodological underpinnings, also exist; for instance: anthropology, psychology, history and political science. ${ }^{13}$

Importantly, in recent years, the study of legal evolution has become more systematic, and there have emerged various approaches to the study of legal evolution. However, until now, there has been no consensus as to which of these approaches is the most appropriate for the purposes of uncovering the mechanisms of legal evolution. This latter point may not be a problem if one respects different scientific views and believes that a variety of theoretical approaches is needed in order to fully understand a phenomenon. Nevertheless, the problem remains that the proponents of the different approaches seldom exchange their views and ideas; scholars of legal path dependency tend to only meet other scholars of legal path dependency, and macro-sociologists tend to only recognise the findings of other macro-sociologists. Interdisciplinary crossfertilisation remains a rather rare occurrence.

In this issue of Erasmus Law Review, as well as the next, the latter problem is addressed by scholars who illustrate the use of different approaches to researching legal evolution. Thus, the value of this double issue of Erasmus Law Review is twofold: firstly, every article is an important contribution to the study of the evolution of law from its own methodological perspective. Secondly, this collection, which encompasses a variety of views on the evolution of law, allows for quick and convenient access to different approaches to this field of research, and therefore provides added value for the reader.

The articles published in the double issue are the research output of a workshop ('Understanding Legal Evolution') that was held at the Erasmus School of Law (Erasmus University Rotterdam) in June 2011. Thereby the production process of the articles not only included in-depth research and the subsequent drafting by the authors, but also the engagement of highly competent commentators at the workshop. These commentators were: Prof. Dr. Yuwen Li (Erasmus School of Law, Erasmus University Rotterdam), Prof. Dr. Thomas Möllers (Faculty of Law, University of Augsburg), Prof. Dr. Dr. h.c. Erich Schanze (Faculty of Law, University of Marburg and University of Bergen), Privatdozent Dr. Jan Schnellenbach (Department of Economics, University of Heidelberg), Prof. Dr. Wouter Veraart (Faculty of Law, VU University Amsterdam). The articles also underwent a double-blind peer review process - the work of the anonymous referees is highly appreciated.

A special thank-you goes to those who have made the workshop possible through generous funding: The Rotterdam Institute of Law and Economics, the Research Program Behavioural Approaches to Contract and Torts at the Erasmus School of Law, the Erasmus School of Law and the Vereniging Trustfonds Erasmus Universiteit Rotterdam.

This brings me to the organisation of articles in this double issue of Erasmus Law Review. The selection of the authors was based on the idea of covering various research perspectives on legal evolution by bringing together specialists in their research fields. As a consequence, the present selection of articles is not an attempt to cover all aspects of legal evolution by assembling survey articles, but is designed to give an impression of the breadth of the discussion on legal evolution, whereby the articles fall into two categories - empirical papers and conceptual papers. Thus, the organising principle is to address the empirical papers in the first issue, and the more conceptual papers in the second issue. The articles will appear in the following order:

\footnotetext{
13 For a recent attempt to integrate various approaches for a better understanding of legal evolution, see S. Deakin, 'Legal Evolution: Integrating Economic and Systemic Approaches', University of Cambridge Faculty of Law Legal Studies Research Paper Series NO. 41/2011 (2011).
} 
Erasmus Law Review Vol. 4(3):

- Nathan Betancourt/Barbara Krug: Rule Proliferation and Institutional Quality in the Enterprise Bankruptcy Law of the People's Republic of China, 1986-2009

- WesleyKaufmann/Arjenvan Witteloostuijn:The Ecology ofEU Competition Law: A Quantitative Analysis of Rule Dynamics and Rule Stock

Erasmus Law Review Vol. 4(4):

- Christian Kirchner: Evolution of Law: Interplay between Private and Public Rule-making

- Hans-Jürgen Wagener: How does Good Governance Come about? On Evolution of Institutions

- Elaine Mak: Understanding Legal Evolution through Constitutional Theory: The Concept of Constitutional (In-)Flexibility

The paper by Betancourt and Krug is concerned with the relatively new bankruptcy law of the People's Republic of China. The authors examine the degree to which the proliferation of bankruptcy provisions, as opposed to the elaboration of the statute, affects organisational compliance with the bankruptcy law. To answer this question the authors undertake a state of the art empirical legal analysis. Thereby many factors are identified which may influence the direction and the progress of legal evolution in general. Kaufmann and van Witteloostuijn use an ecological approach, which posits that, apart from external pressures, an internal dynamic is a key driver for the production of legal rules. With the example of European competition law they can show that an ecological approach is not only a strong empirical approach in organization science, but that it can be applied also fruitfully to the study of legal evolution. The paper by Kirchner elaborates on the interplay between private and public rule-making, making clear that legal evolution can only be understood, if both domains of law are considered in parallel. Wagener asks "how does good governance come about?" He examines the possibilities and constrains of politics to influence legal evolution towards better institutions, from which society benefits as a whole. Eventually, Mak analyzes legal evolution from the perspective of constitutional theory. She argues that constitutional theory provides a framework for a better understanding of why institutions of government develop differently in western democracies.

In summary, the contributions to this and the next issue of Erasmus Law Review provide a broad insight to the evolution of law, based on their various disciplinary backgrounds. 